\title{
The inselberg landscape in Finnish Lapland: a morphological study based on the LiDAR data interpretation
}

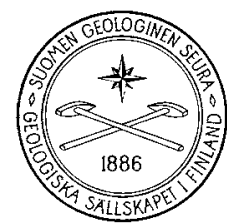

VERTAISARVIOITU KOLLEGIALT GRANSKAD KOLLEGIALT GRANSH

\author{
Keijo Nenonen ${ }^{\mathrm{I}}$, Peter Johansson ${ }^{2}$, Olli Sallasmaa ${ }^{\mathrm{I}}$, \\ Pertti Sarala ${ }^{2^{*}}$ and Jukka-Pekka Palmu ${ }^{\mathrm{I}}$ \\ ${ }^{1}$ Geological Survey of Finland, P.O. Box 96, FI-02151 Espoo, Finland \\ ${ }^{2}$ Geological Survey of Finland, P.O. Box 77, FI-96101 Rovaniemi, Finland
}

\section{Abstract}

An advanced method to study geomorphology of the well-known inselberg landscape in Finnish Lapland is introduced. Conventionally topographical maps and altitude reference produced from stereographic aerial photographs has been used. Now the LiDAR data has opened a new way to study geomorphology and terrain in detail. We applied the new methods in eastern Finnish Lapland from where seven inselbergs have been identified and analysed. With an accurate elevation data and images we could identify the detailed morphology in the inselbergs and examine the processes that actively alter the terrain. LiDAR data opened a view to the preglacial history and processes. Some preliminary estimations of the rate and amount of preglacial erosion could be made. It seems that erosion rate may have been in order of 2-10 m/Myr in Lapland based on existing datings and stratigraphic observations. Weathering and erosion history in Lapland is long as the kaolinite clays of Late Cenozoic, Mesozoic or even Mesoproterozoic in age are found in the weathered bedrock. Although all disconformities older than the Mesozoic era have probably been eroded to an unidentifiable extent, there is good reason to suppose that the main characteristics of the relief, including inselbergs, originated as early as the Late Cretaceous or at least in the Palaeocene.

Keywords: Inselbergs, tor formations, pre-glacial weathering, LiDAR technology, erosion rates

*Corresponding author (e-mail: pertti.sarala@gtk.fi)

Editorial handling: Juha-Pekka Lunkka (juha.pekka.lunkka@oulu.fi) 


\section{Introduction}

Preglacial weathering profile and erosional landforms are well preserved in Northern Europe and Finland (Migon', 1996). The area stood repeatedly in the ice divide zone of the former Pleistocene glaciations and thus the glacial erosion has been weaker than in areas south of the Polar Circle. Abundantly interglacial organic deposits and remains of preglacial deep weathering are found from the Central Lapland (Hirvas et al., 1988; Hirvas, 1991; Hall et al., 2015). So far the long term erosion rates and the dating of the main episodes of weathering and erosion are poorly understood.

In this study, we applied the new LiDAR (Light Detection And Ranging) technology to investigate older geomorphological features such as erosional residual hills, i.e. inselbergs. The term 'inselberg' comes from the German Insel, meaning "island," and Berg, meaning "mountain" (Holmes, 1978). It refers to an isolated hill that stands above welldeveloped plains and appears like an island rising from the sea. Inselbergs are relict features formed under warmer climates than the present.

An inselberg can be an isolated bedrock hill, knob, rocky ridge, or a small mountain that rises abruptly from a gently sloping or virtually level surrounding plain. Plains containing various inselbergs, i.e. inselberg plains, occur in various parts of the world, including the interior of the Sahara desert, the southern part of Africa, South America, the USA and Canada, Brazil, Venezuela, the Northern Territory of Australia and in Lapland, the northernmost province of Finland and Sweden (Thomas, 1965, 1978; Lidmar-Bergström, 1996; Migoń, 1997; Ahnert, 1998; Ebert \& Hättestrand, 2010). Inselbergs are fairly common geomorphological features, especially in weathered and levelled cratons and shields.

The use of LiDAR data has opened a new way to study geomorphology and terrain in considerable detail. In Finland, LiDAR data are produced and delivered by the National Land Survey. The method is based on laser altitude measurements from a flight altitude of $2000 \mathrm{~m}$, so that the laser beam emitted from the aircraft has a footprint of $60 \mathrm{~cm}$ on the ground. The average measurement density is 0.5 per square metre of ground and the elevation accuracy is at best $15 \mathrm{~cm}$. The bulk of laser measurements form a digital point cloud that can be processed and handled geometrically. With modern data handling methods and powerful computers, large quantities of geometric data can be rapidly modelled and processed online. However, LiDAR DEM (digital elevation model) has so far been used mostly to study glacial geomorphology (Johnson et al., 2015; Ojala et al., 2015; Putkinen et al., 2017) and Holocene geomorphology (Sarala et al., 2015), mires, hydrological catchment areas (Johansson \& Palmu, 2013) or human impact in terrain (Risbøl et al., 2008; Koivisto \& Laulumaa, 2012).

\section{Earlier studies}

A detailed morphometric analysis of the genesis of landforms and the geomorphology in Finnish Lapland was first carried out in the 1960`s (Kaitanen, 1969, 1985). By combining aerial photographs and the interpretation of topographical maps, tor- and cirque-like forms were commonly identified in the area. The tors were found to mostly occur in the summit areas of hills or in slope curvature zones. Tors are minor erosion features, typically being just a few meters in height above the surrounding terrain, but the largest formations are almost $10 \mathrm{~m}$ high. Kaitanen (1969, 1985) concluded that the upper relief and erosion on top of the hills dated back to pre-glacial times, possibly to the middle and early Tertiary (i.e. Paleogene period), comparable to pediplanation conditions. During the Pleistocene erosion on the hilltops appeared to be minor. The lower relief valleys and fluvial drainage pathways were then formed during the Pliocene and interglacial phases of the Pleistocene. Lowlands south of and close to the Inarijärvi lake basin were marked with intense glacial streamlined moraine forms, drumlins and flutings. The present relief has inherited the structures of older pre-glacial erosional relief that 
had developed during a long time span since the Proterozoic eon.

In the study area of eastern Finnish Lapland (size $32000 \mathrm{~km}^{2}$ ), it has been possible to distinguish a total of 60 landforms that fulfil the strictest criteria for inselbergs, i.e. the clearness of a foot nick and steepness of hill slopes (Kaitanen, 1969). However, it is not presently possible to decide which of the two alternative planation models, namely etchplanation or pediplanation, should be assigned greater importance in explaining relief evolution. Later, Kaitanen (1989) defined the relationships between ice-sheet dynamics and bedrock relief on a dissected plateau area in the Muotkatunturi fells, located in the northernmost Finnish Lapland. It was found that the bedrock residuals are predominantly the foundations of former tors, kopjes and inselbergs. The ice sheet dynamics had been weak, so that the pre-glacial weathering forms had largely also been preserved in the Muotkatunturit fell area. Intense glacier flow at lower elevations and in valleys had affected the area during the final phase of the latest glaciations and many earlier periods of glaciations.

The long-term geomorphological evolution of inselbergs and pre-glacial landforms on a glaciated terrain has also been examined in northern Sweden by Ebert et al. $(2012,2015)$. The relief of the study area covers $33,000 \mathrm{~km}^{2}$, and an abundance of inselbergs exists in the centre of the area. According to their results, the shield surface had largely been stripped of pre-Quaternary correlative sediments and saprolites, and glacial erosion had only a minor impact on the large-scale bedrock morphology of northern Sweden.

The effect of weak erosion was also recognized in excavations and observations during the Nordkalott project in 1980-1986 (Hirvas et al., 1988). Especially in the ice-divide zone, weathered bedrock and interglacial-interstadial organic sediments had been preserved under the glacier during Quaternary glaciations (Hirvas et al., 1988; Johansson et al., 2011). It is inferred that the coarse gruss weathering, resulting in a saprolite cover of up to $10-20 \mathrm{~m}$ in thickness, evidently occurred in the Neogene. Inselbergs are considerably higher than this, and must therefore be remnants of some older deep weathering and erosional events. Fracture zones associated with deep kaolin occurrences, found in northern Fennoscandia, may represent the roots of older generations of deep weathering cover. However, their age and formation is still unclear, although the position of kaolinitic sediments in sedimentary sequences in southern Sweden and the Barents Sea in the north refers to the Mesozoic, i.e. Jurassic age (Sarapää, 1996).

Some evidence for a Proterozoic age of the deep kaolin weathering in Finland has been reported by Sarapää (1996). The K-Ar age of the kaolin deposit at Litmanen in Virtasalmi is $1179 \pm 19$ Ma. The kaolinitic sediments with Late Riphean and Early Vendian microfossils occurring in the Iso-Naakkima impact carter in Pieksämäki south-eastern Finland close to Virtasalmi confirm the Neoproterozoic age of the Virtasalmi kaolin (Elo et al., 1993). Similar impact crater is also in Taivalkoski, northern Finland where Saarijärvi meteorite crater is filled with unusual occurrence of un-metamorphosed kaolin-bearing clay-, silt-, and sandstones, which were dated to Neoproterozoic of age. Microfossil studies has confirmed a Neoproterozoic (Ediacaran, or Vendian) age of approximately $600 \mathrm{Ma}$ for the kaolin bearing sediments (Öhman \& Preeden, 2013; Tynni \& Uutela, 1985). So deep weathering in northern Finland may also be of Neoproterozoic age. This can be seen in Kilpisjärvi, the northernmost Lapland where the Saanatunturi - Haltitunturi nappe contains a well-developed stratigraphy of Caledonian basal sedimentary unit, the Dividal Group of latest Proterozoic - Cambrian age. Sedimentary section with conglomerates, sandstones, claystones and dolomites lies on an unconformity plane representing a hiatus of up to two Ga of erosion and weathering (Lehtovaara, 1995).

The positions and footprints of the inselbergs are often closely controlled by the bedrock type and its fracturing. Granite inselbergs often have dome forms, where the dome shape and slopes are determined by exfoliation joint patterns. These links indicate the fundamental importance of etch 
processes in shaping the relief through multiple cycles of deep weathering and stripping by erosion. Palaeosurfaces have been extended and lowered through time, with the isolation of small inselbergs during the erosion of higher relief. This process has formed a widely stretched, poorly stripped Pliocene etchplain (Söderman, 1985) or recently interpreted monandnock plain with inselbergs in northern Fennoscandia (Lidmar-Bergström \& Olvmo, 2015). However, the timescales for relief generation are uncertain, and there is a need to understand the significance of weathered bedrock and to date the stripping sediments, saprolites and weathered ore bodies that rest on the surface of the northern Fennoscandian shield.

In a recent study by Lidmar-Bergström \& Olvmo (2015) on the plains, steps, hilly relief and valleys in northern Sweden, the historical development of observations, ideas and concepts in the field of large-scale geomorphology in northern Sweden were reviewed. The relief differentiation of basement rocks was recognized early in flat areas, and in many settings they were identified as a sub-Cambrian peneplain. Undulating hilly relief extends over large areas of central and northern Sweden, but no explanation was presented. Plains with residual hills in stepped sequences were also identified, particularly in the far north, and explanations could be found in the international literature (Rudberg, 1960). Recent findings have provided arguments for the differential uplift of three Scandinavian domes: the Northern Scandes, the Southern Scandes and the South Swedish Dome. Lidmar-Bergström \& Olvmo (2015) also summarized the arguments for the view that glacial erosion had generally little effect on the largescale landscape. The relief of re-exposed surfaces in southern Sweden and plateaus in Norway and Greenland also supports the hypothesis for the reconstruction of stepped peneplains in the Swedish mountains. The Swedish approach, with relief descriptions and studies on the relationship between basement relief covers, has been found to be a good method for drawing conclusions on Phanerozoic tectonics in the basement.
Hall et al. (2015) in their paper on Late Cenozoic deep weathering patterns in the Fennoscandian Shield in northern Finland, demonstrated that geology is closely linked to topography in the preglacial shield landscape of northern Finland, and both factors influence weathering patterns. Upstanding, resistant residual hills or inselbergs of granulite, granite, gabbro, metabasalt and quartzite rocks were associated with fresh rock outcrops, including tors, or with thin $(<5 \mathrm{~m})$ grusses. Plains developed across less resistant biotite gneisses, greenstones, and belts of alternating rock types were mainly weathered to thick $(10-20 \mathrm{~m})$ grusses. Beneath the valley floors that developed along mineralised shear and fracture zones, weathering locally penetrated to depths of $>50 \mathrm{~m}$ and included intensely weathered kaolinitic clays. The authors also confirmed that glacial erosion has been limited $(<20 \mathrm{~m})$ in northern Finland and has been widely restricted to the partial stripping of saprolite. The Fennoscandian Ice Sheet in the Central Lapland ice-divide zone remained cold-based and un-erosive throughout most of the Pleistocene. According to Hall et al. (2015, 2017), the large-scale shield geomorphology evidently developed before glaciation and is a product of differential weathering and erosion acting on diverse rock types and structures thought to date back to the Neogene.

\section{The use of geomorphological data in detecting inselbergs, monadnocks or residual hills}

According to our definition, the terrain surrounding inselberg should be an erosional footslope, inclined at a low angle, lacking significant relief and meeting the hillslope foot with a clear angular nickline. The hill slopes should also be steep. Kaitanen (1985) developed a typology for inselbergs, residual hills and monadnocks in Finnish Lapland. First: At least $75 \%$ of inselbergs circumference there should 
be clear break in slope so that slope gradient is duplicated in $20 \mathrm{~m}$ vertical distance from footslope to hillslope trough incline in question. Secondly: In the hillslope area slopes (measured as a proportion of length of the borderline) must predominate, with certain minimum inclinations.

In eastern and southeastern Finnish Lapland, only seven hills fulfil the requirements for pure inselbergs (Kaitanen, 1985). They are from south to north as follows: Suomutunturi (Kemijärvi), Pyhätunturi (Pelkosenniemi), Sattasvaara (Sodankylä), Postovaara (Sodankylä), Lattunavaara (Savukoski), Naltiotunturi (Savukoski) and Terävä Nattanen (Sodankylä). Altogether, 60 formations from the same area can be classified as less pure or least pure inselbergs. In many cases, the Finnish and Swedish geographical names "vaara", "tunturi", "berg" and "fjell" can be regarded as referring to residual hills, monandnocks or inselbergs.

According to this typology and set of requirements, we performed a preliminary analysis based on open access LiDAR data published from Finnish Lapland north of the polar circle using the Maankamara map server of the Geological Survey of Finland (GTK; http://gtkdata.gtk.fi/Maankamara/ index.html). This free web map application includes features such as precise elevation data hillshading, superficial deposits and bedrock maps and aerial photographs.

GTK has implemented a multidirectional hill shading technique for the new application. The elevation data increases the value of the superficial deposits maps and makes them easier to interpret. The National Land Survey of Finland provided the base maps and aerial photographs for the Maankamara application. The basic elevation models and laser scanning basic data were also produced by the Land Survey of Finland. It was processed and visualized by GTK.

The superficial deposit maps are available at scales of 1:1000000, 1:200000, 1:50000 and 1:20000, while the bedrock maps are available at scales of 1:1000000 and 1:200000. GTK's Maankamara application maps can already display elevation differences within an accuracy of
0.3 metres for $80 \%$ of the Finnish land area. The accuracy of maps available for the whole of Finland is currently 1.4 metres.

The map application offers the best possible geological mapping data from each area and can be smoothly scaled. The readability and clarity of the map view can be improved by adjusting the transparency of the map themes.

\section{Analysis of inselbergs in LiDAR data from Finnish Lapland}

For the geomorphological analyses the LiDAR DEMs produced by the National Land Survey of Finland (http://www.maanmittauslaitos.fi/en/ professionals/topographic-data/remote-sensing/ laser-scanning), was used. It refers to threedimensional point-like data depicting the ground and objects on the ground. Each point is provided with $\mathrm{x}, \mathrm{y}$ and $\mathrm{z}$ coordinate information. The data is collected in order to produce an accurate nationwide 2 m elevation model. Currently LiDAR data is available from most parts of Finland. It can be acquired as versions that are restricted by area and in which the laser scanning points are classified either automatically or with the help of stereo models.

The product is a part of the open data of the National Land Survey of Finland. According to National Land Survey of Finland, an automatically classified point cloud has been processed to form the foundation for the nationwide elevation model and to be suitable as source data for the interactive production of the elevation model. The data was filtered and classified according to geomorphological needs. The laser point density is at least 0.5 points $/ \mathrm{m}^{2}$, i.e. the mean distance between laser points is at most approx. $1.4 \mathrm{~m}$. Regarding unambiguous objects, the standard error of the elevation accuracy is at maximum $15 \mathrm{~cm}$ and the standard error in planimetric accuracy $60 \mathrm{~cm}$. 
The LiDAR DEM is a geometric mathematical dataset of geomorphological ground surface, so it can be utilized in various geomorphological calculations and visualizations of geological ground targets. The LiDAR DEM of $2 \mathrm{~m}$ cell (pixel) size was processed by Geological Survey of Finland from LiDAR cloud point data. The DEM processing was carried out with ESRI ArcGIS software, version 10.3. The Spatial Analyst extension tools were used, and a slope raster was calculated from the DEM. The data were processed with the Degree option, i.e. the slope steepness values are in degrees. The LIDAR elevation data is geometrically more accurate than the topographic maps than where used before to geomorphological evaluations.

Slope data classification was based on Kaitanen (1985). The inselbergs were divided into three classes: a) 'pure' inselberg, b) 'less pure' inselberg and b) 'least pure' inselberg. After Kaitanen's (1985) typology in "pure inselbergs" at least $95 \%$ of the slopes should be steeper than $18^{\circ}$ and at least $50 \%$ of slopes steeper than $27^{\circ}$. In "less pure inselbergs" accordingly at least $75 \%$ of the slopes steeper than $18^{\circ}$ and at least $25 \%$ of slopes steeper than $27^{\circ}$ and in "least pure inselbergs" at least $50 \%$ of slopes steeper than $18^{\circ}$ and at least $5 \%$ of slopes steeper than $27^{\circ}$.

\section{Results}

Kaitanen's (1985) study has been so far the most advanced study of inselberg geomorphology, geometry and typology from Finnish Lapland. According to his typology, 7 formations of 60 fulfilled the criteria for pure inselbergs. From those five inselbergs were chosen for detailed examination in the eastern Finnish Lapland (Fig. 1). The laserscanned relief of the area was then calculated and visualized according to Kaitanen's (1985) typology to determine how well the new method works in accurate geomorphological analyses (Fig. 2, Table 1). As the LIDAR data is in mathematical, geometrical form, it is relatively easy and rapid to compute and calculate the laser point cloud data.

The first requirement for an inselberg is to have a clear slope steepness change, a "nick" at the lower part of the inselberg. With the "Focal statistics"function we calculated for every DEM raster cell (pixel) a height range by using the minimum and maximum height values within a $10 \mathrm{~m}$ (5 pixel) radius. The target inselbergs were delineated using $5 \mathrm{~m}$ height range (Fig. 3). From these delineated target areas histograms of slope steepness variability were calculated with the "Zonal histogram" function. This steepness variability is presented in Figs 2 and 3.

According to previous typology, more than $95 \%$ of the slopes of a 'pure' inselberg should be over $18^{\circ}$ and $50 \%$ should be over $27^{\circ}$. The steepest of the five inselberg examined is Sattasvaara, which, however, fails to fulfil these strict demands. Sattasvaara does not even fulfil the requirements for the class of 'less pure' inselberg: only $66.4 \%$ of the slopes are over $18^{\circ}$, which falls short of typology requirement of $75 \%$, and Sattasvaara is thus classified as a 'least pure' inselberg, even though the requirement for the area with over $27^{\circ}$ slope is fulfilled at $35.1 \%$ (requirement $25 \%$ ).

Of the other four hills, only Pyhätunturi, Noitatunturi in Pyhä-Luosto national park fulfils the 'least pure' inselberg criteria of $5 \%$ of the slope being over $27^{\circ}$ and $50 \%$ over $18^{\circ}$, and the former requirement only narrowly.

Terävä Nattanen is situated at the highest elevation of the examined inselberg hills studied. Its lower boundary lies at $361 \mathrm{~m}$ a.s.l., whereas for the others, the lower boundaries are between 213 and $266 \mathrm{~m}$ a.s.l.. Pyhätunturi, Noitatunturi has the highest range of the five, i.e. the height difference between the topmost and lowermost points within a target area boundary (Fig. 2).

The LIDAR geomorphological study shows that accurate laser scanning digital point cloud material enables to make analyses and maps of inselbergs easier and more rapidly than earlier when only manual measuring from topographic maps or terrain survey where possible. Previously accuracy of location in topographic maps was just some $10 \mathrm{~m}$ and height accuracy $2.5 \mathrm{~m}$ as it by modern methods with LIDAR is less than $2 \mathrm{~m}$ and height accuracy $15 \mathrm{~cm}$. 


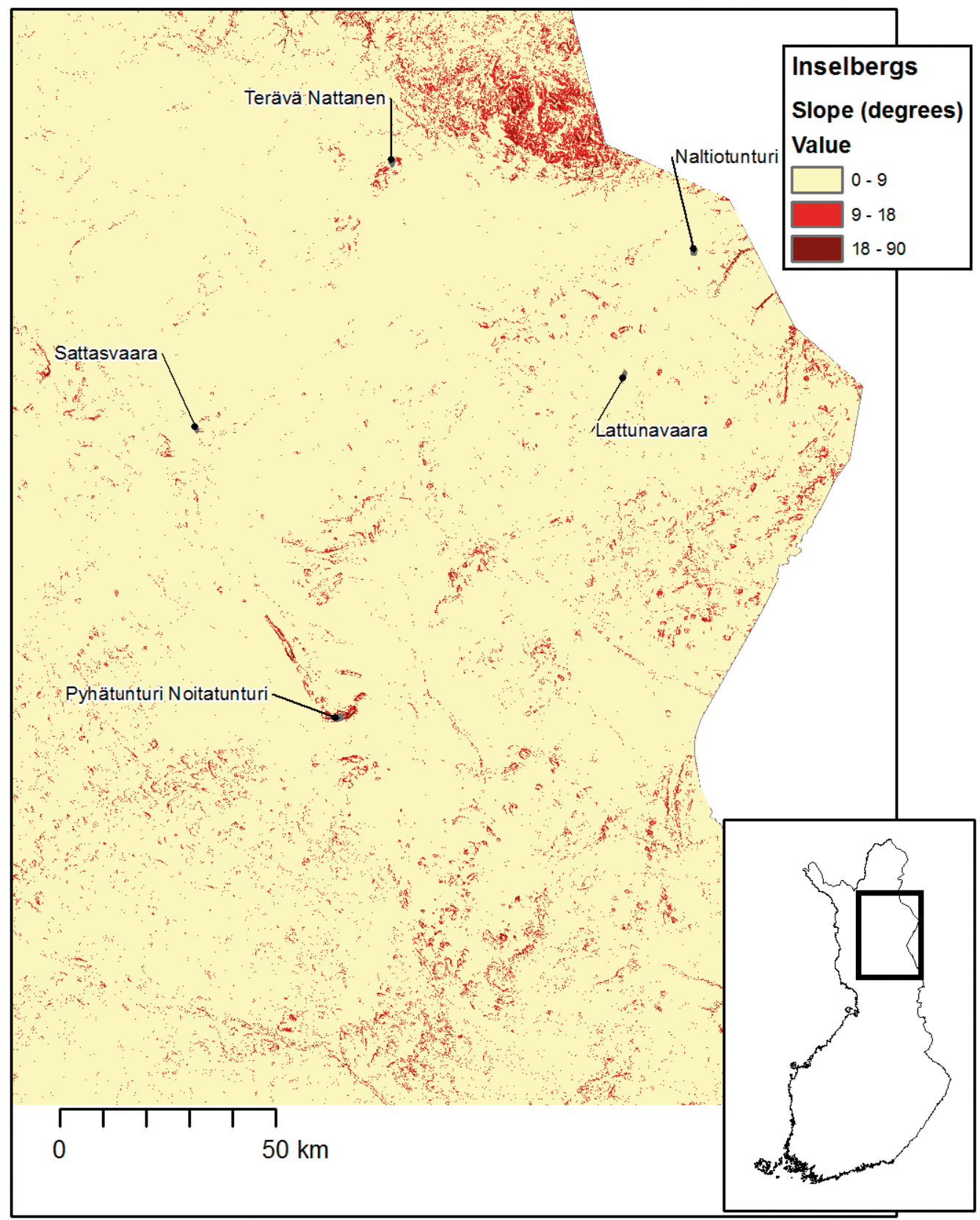

Figure 1. The study area in the eastern Finnish Lapland. Slope steepness of the terrain processed from the digital elevation data of the National Land Survey of Finland. In the north of the study area is the Saariselkä fell area, uplands composed of garnet-cordierite gneiss granulites, with the highest hilltops and evidently also inselbergs reaching 600-700 $\mathrm{m}$ a.s.l. 
Table 1. Slope steepness proportions (including cumulative count, c\%) of five inselbergs based on the LiDAR point cloud.

\begin{tabular}{|c|c|c|c|c|c|c|c|c|c|c|}
\hline \multirow{2}{*}{$\begin{array}{r}\text { Slope } \\
\text { (degrees) }\end{array}$} & \multicolumn{2}{|c|}{$\begin{array}{c}\text { Pyhätunturi, } \\
\text { Noitavaara }\end{array}$} & \multicolumn{2}{|c|}{ Terävä, Nattanen } & \multicolumn{2}{|c|}{ Naltiotunturi } & \multicolumn{2}{|c|}{ Sattasvaara } & \multicolumn{2}{|c|}{ Lattunavaara } \\
\hline & $\%$ & $\mathrm{c} \%$ & $\%$ & $\mathrm{c} \%$ & $\%$ & $\mathrm{c} \%$ & $\%$ & $\mathrm{c} \%$ & $\%$ & $\mathrm{c} \%$ \\
\hline $0-5$ & 2.1 & 2.1 & 1.2 & 1.2 & 1.8 & 1.8 & 3.7 & 3.7 & 1.1 & 1.1 \\
\hline $5-9$ & 7.3 & 9.3 & 5.4 & 6.5 & 6.7 & 8.5 & 6.2 & 9.9 & 5.5 & 6.6 \\
\hline $9-13$ & 15.4 & 24.7 & 15.9 & 22.4 & 15.8 & 24.2 & 9.1 & 19.0 & 11.6 & 18.1 \\
\hline $13-18$ & 24.2 & 48.9 & 31.2 & 53.7 & 27.1 & 51.3 & 14.7 & 33.6 & 32.2 & 50.3 \\
\hline $18-27$ & 32.2 & 81.1 & 37.8 & 91.5 & 37.4 & 88.7 & 31.3 & 64.9 & 46.8 & 97.1 \\
\hline $27-36$ & 14.2 & 95.3 & 8.1 & 99.6 & 11.1 & 99.8 & 29.9 & 94.8 & 2.9 & 100.0 \\
\hline $36-90$ & 4.7 & 100.0 & 0.4 & 100.0 & 0.2 & 100.0 & 5.2 & 100.0 & 0.0 & 100.0 \\
\hline Area $\left(m^{2}\right)$ & \multicolumn{2}{|c|}{1866936} & \multicolumn{2}{|c|}{797136} & \multicolumn{2}{|c|}{747128} & \multicolumn{2}{|c|}{273724} & \multicolumn{2}{|c|}{534136} \\
\hline
\end{tabular}

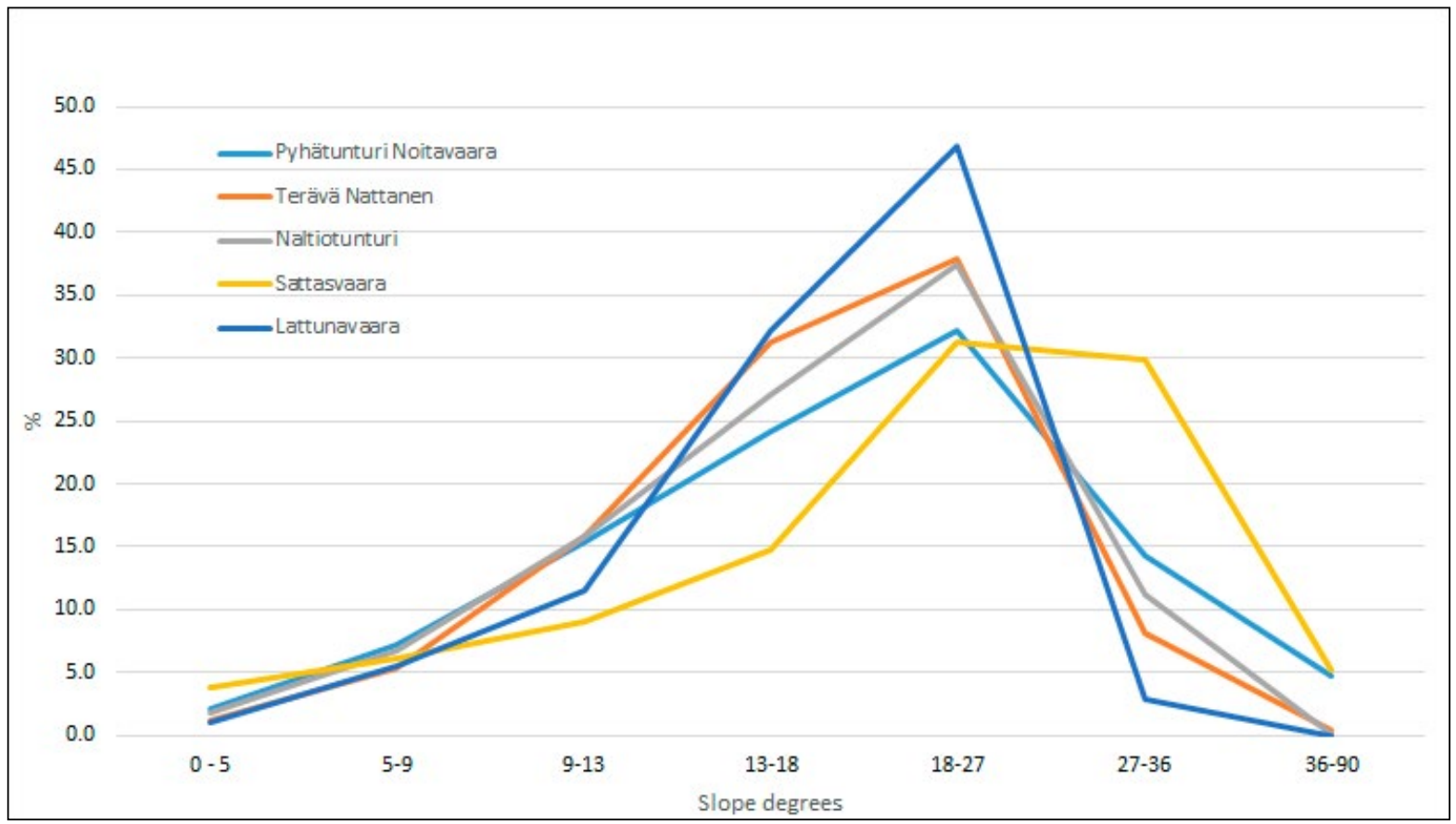

Figure 2. Statistics of the slope deepness in the chosen inselbergs calculated based on data presented in Table 1.

\subsection{Nattanen inselbergs in Sodankylä}

The Nattaset fells are a group of high, cone-shaped hills situated in the northern part of Sodankylä (Fig. 1), in the Sompio Nature Reserve. The peaks reach over $500 \mathrm{~m}$ a.s.l., with the highest, Terävä-
Nattanen, at $544 \mathrm{~m}$. The Nattaset fells consist of red, coarse-porphyritic or even-grained, homogeneous granite that is composed of plagioclase, quartz and $\mathrm{K}$-feldspar in equal proportions. Biotite is the main mafic mineral, and accessory phases include magnetite, allanite, sphene and zircon (Front et al., 1989). The Nattaset fells all belong to 
Figure 3. Examples of "pure" inselbergs identified according to Kaitanen's (1985) typology from the study area. Accurate geometric LIDAR material enables to make analyses and maps of hill slopes easier and more rapidly than earlier when only manual measuring from topographic maps or terrain survey where possible.
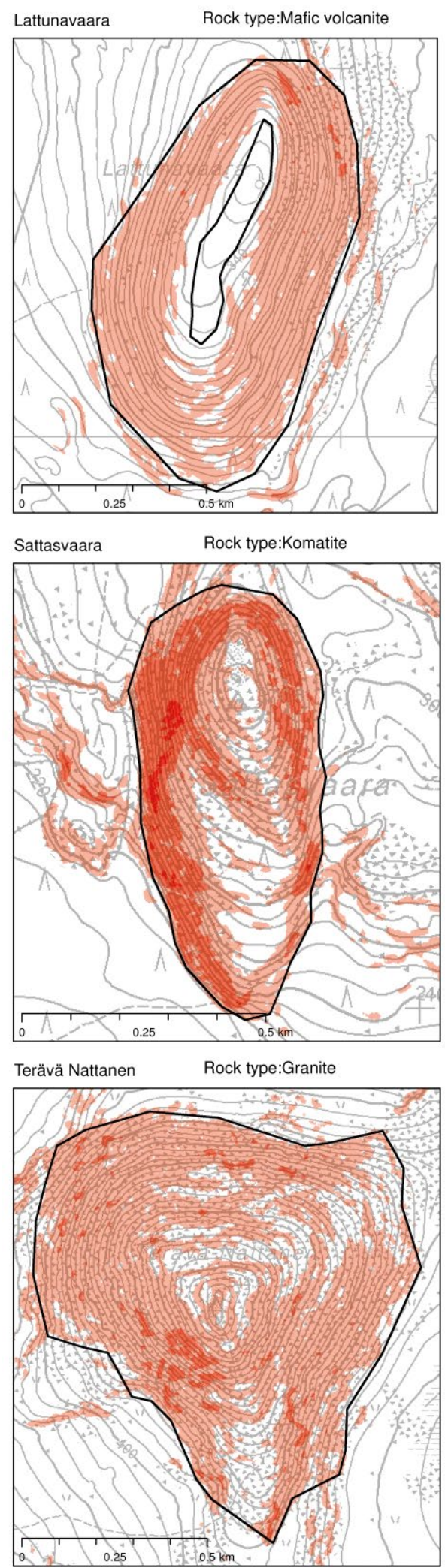

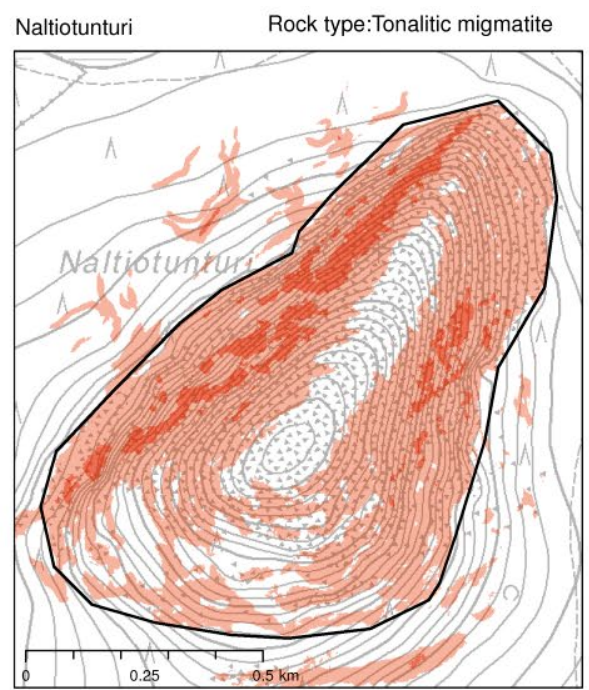

Pyhätunturi Noitatunturi Rock type:Quartzite

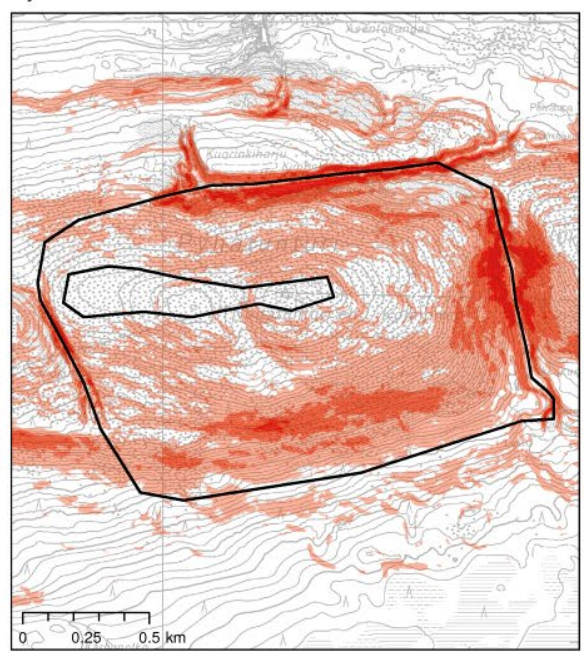

\section{Inselbergs}

$\square$ Hill slope area

Vertical range within $10 \mathrm{~m}$ radius meters

\begin{tabular}{|l|l}
\hline & $0-5$ \\
$\square$ & $5-10$ \\
$10-15$ \\
$15-20$
\end{tabular}




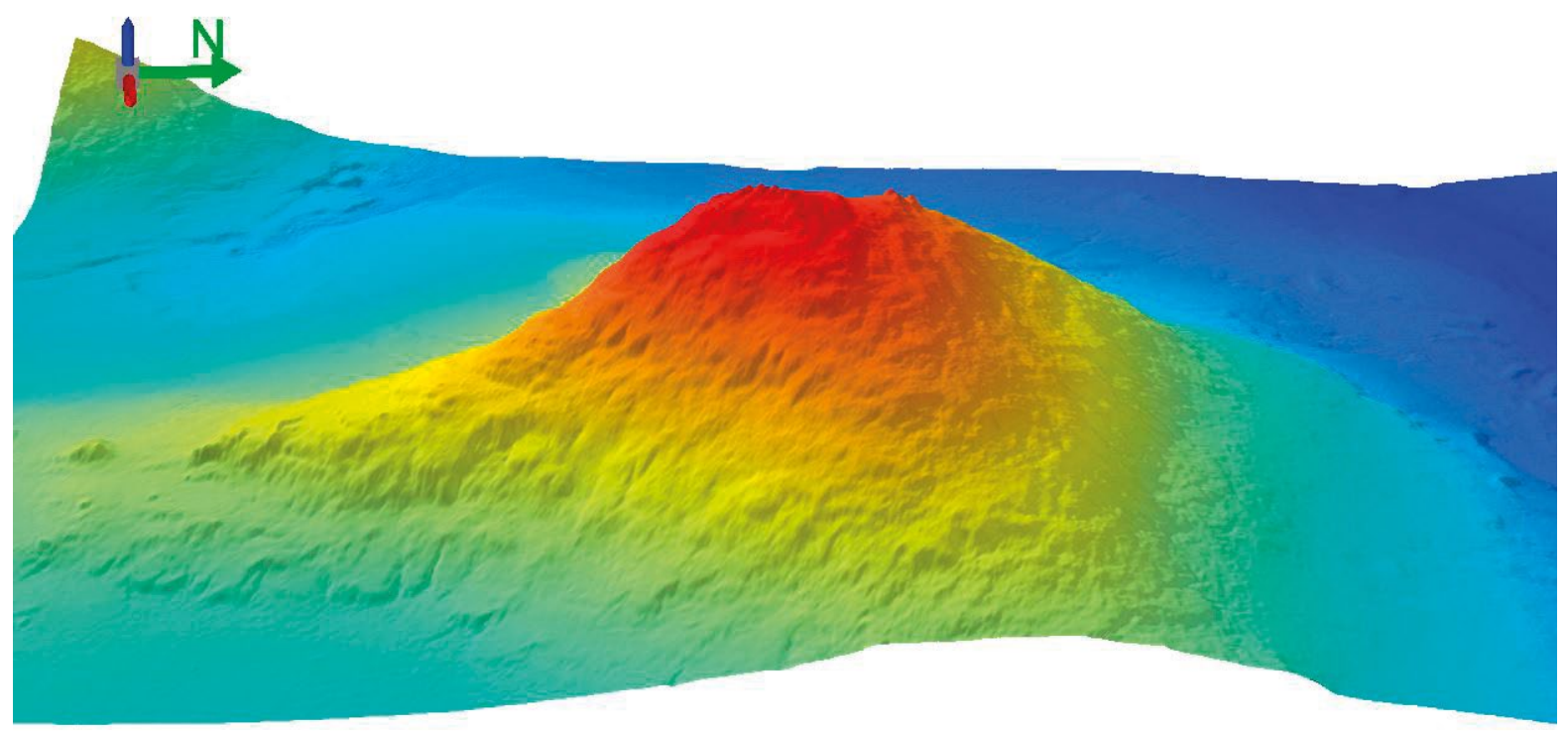

Figure 4. Terävä-Nattanen granitic inselberg. View from the east. Image produced with ArcScene software from LiDAR point cloud data of the National Land Survey of Finland processed into a DEM by GTK. Vertical exaggeration 2. Map area $1668 \mathrm{~m}(\mathrm{~W}-\mathrm{E}) \times 2652 \mathrm{~m}(\mathrm{~N}-\mathrm{S})$. Elevation between 287.4-546.1 m a.s.l. Note the tor knobs in the summit area of the inselberg. Granite fracture patterns can be inferred on the upper slopes of the fell.

a 1.77-Ga-old granite intrusion that is one of the youngest post-orogenic rock types in the area. The granite-intruded granulites were formed in the middle crust during the Lapland-Kola orogeny ca. 1.9 Ga ago. On the southern side of the Nattaset fells, the bedrock consists of Archaean, over 2.5-Ga-old gneisses (Heilimo et al., 2009).

The outcrops on the Nattaset fells show typical horizontal subfracturing that formed during the cooling and uplift of the granite pluton. The horizontal and vertical fractures broke the granite into blocks. Weathering mostly took place along the fractures, leaving the central blocks intact. Subsequent erosion and solifluction removed the more broken rocks, leaving the block piles or tors on the felltops intact. The remaining tors survived the ice ages due to the fact that the ice-divide zone was located in the area and the continental ice sheet was practically immobile (Darmody et al., 2008). Tor formations exist in different parts of the Nattaset fell group, for example on the fell tops of Suku-Nattanen, Terävä-Nattanen (Fig. 4) and Seinätunturi, but the tors on the Pyhä-Nattanen fell are the most well-known (Fig. 5a and b). They cover the fell top at a level of 450-500 m a.s.l. The largest rectangular piles are $7-9 \mathrm{~m}$ high and 40-50 m wide.

The tors are also observed on the Riestovaara (385 m a.s.l.) and Riskaskama (420 ma.s.l.) hills, on the southern side of the Lokka Reservoir (Fig. 1). The bedrock of these hills is composed of granite similar to the Nattaset fells. Age determinations using cosmogenic nuclides $\left({ }^{10} \mathrm{Be}\right.$ and ${ }^{26} \mathrm{Al}$ ) have constrained the combined exposure and burial history age of the tor formations to $850000-1$ million years, suggesting that they have survived multiple (14-16) glacial periods (Hättestrand \& Stroeven, 2002; Darmody et al., 2008). Thus, it is evident that the tor formations in Lapland are preglacial, dating back to at least the early Pleistocene. LIDAR data gives detailed geometric information of the fells slopes thus enabling geological and geomorphological studies and observations of for example granitic sheet and fracture structures and solifluction slopes (Figs. 5b and 6). 
Figure 5. a) Tor formations at the top of the Pyhä-Nattanen inselberg. The sub-horizontal fractures are well developed in the tor. View from top of the Pyhä-Nattanen fell toward west. b) a detailed clipping (on sale of 1:4000) of LiDAR point cloud data of the National Land Survey of Finland. The LIDAR data is processed with ArcMap software and hillshading is attached to the image. The Pyhä-Nattanen tors shown in Fig. 5a are marked with black circle. Sheet structures in the granite can be observed and also solifluction lobes, which are well developed on the lower slopes of the inselberg. Photo by P. Johansson.
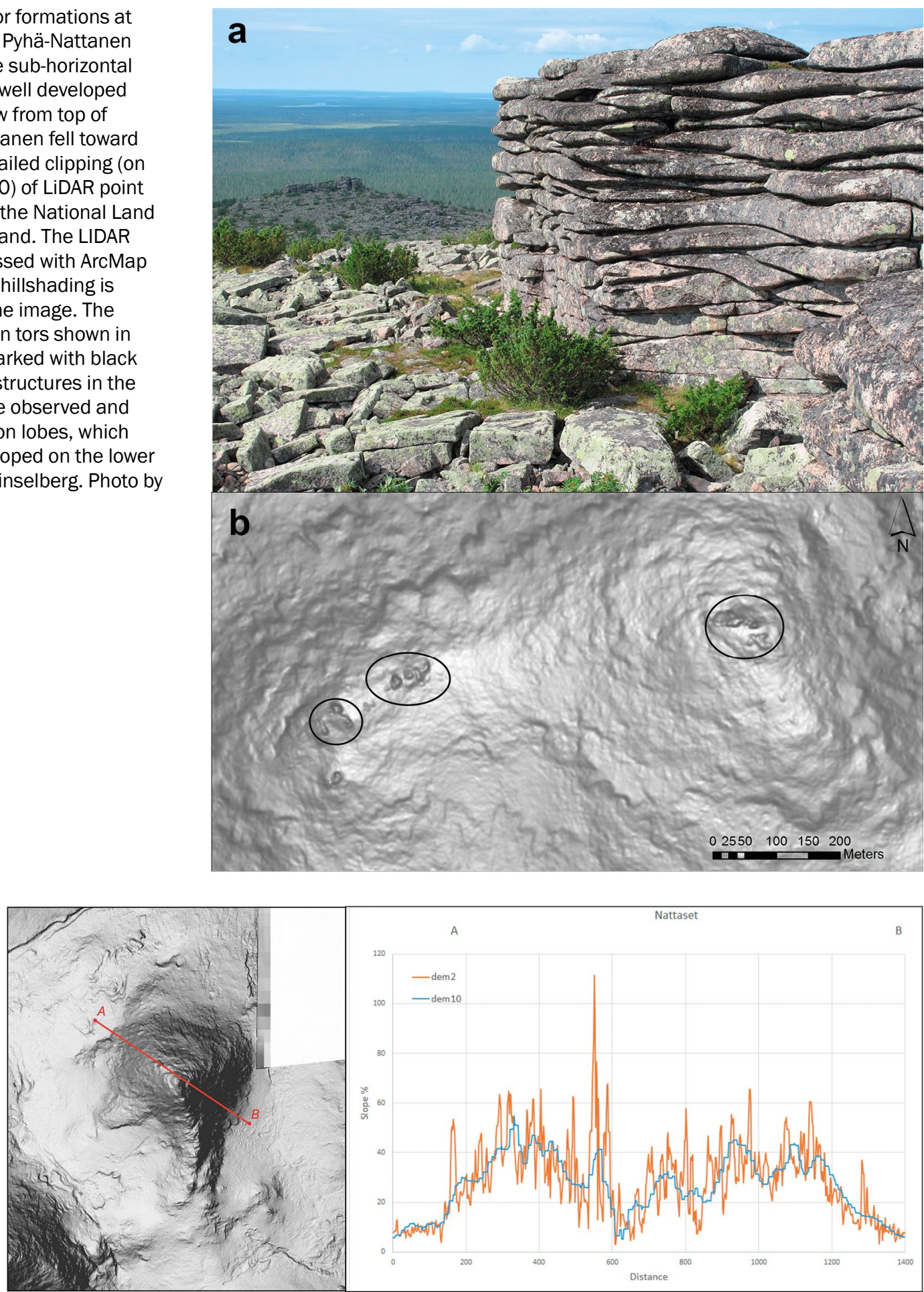

Figure 6. The variety in slope on a measuring line over the Terävä-Nattanen inselberg. Detailed laser scanned geometric information by red contour (dem2) shows a step like variation in slopes caused partially by solifluction lobes and cubical fracturing of the Nattanen granite. The tor formation on the top of the Nattanen fell is shown in the slope angle maximum in the diagram. Blue contour (dem10) shows the slope angle variation on $10 \mathrm{~m}^{2}$ grid giving more generalised view to slope steepness fluctuations. 


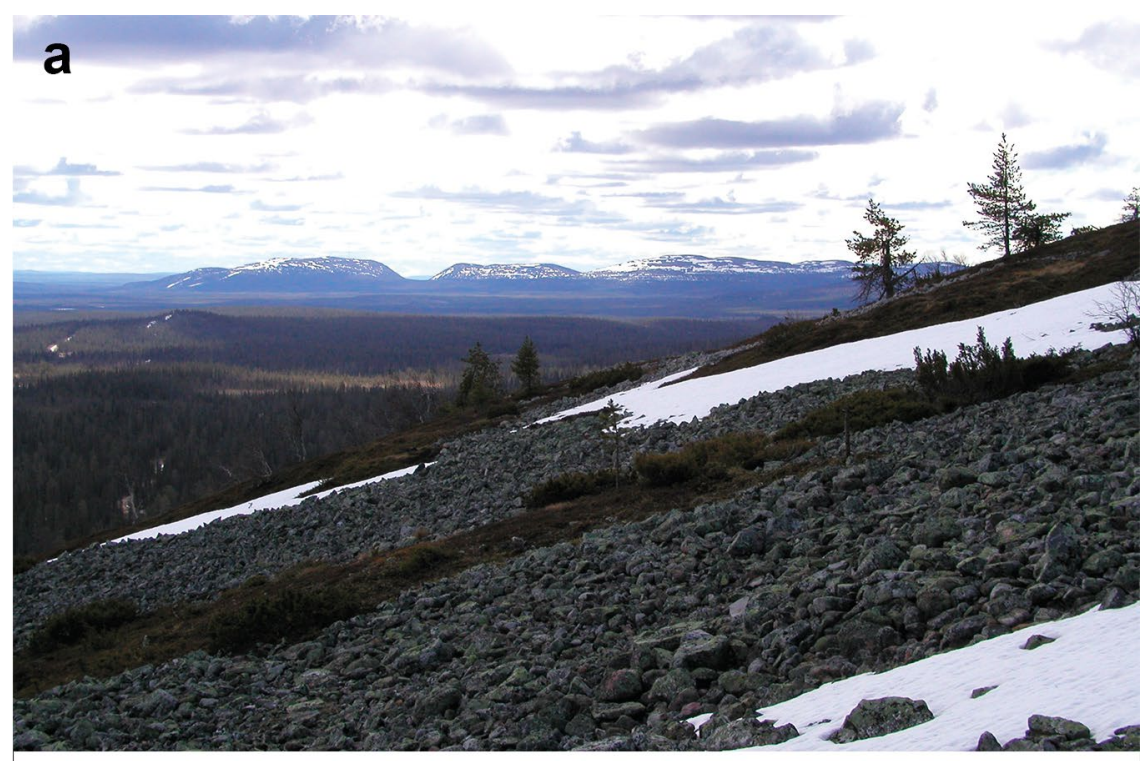

b

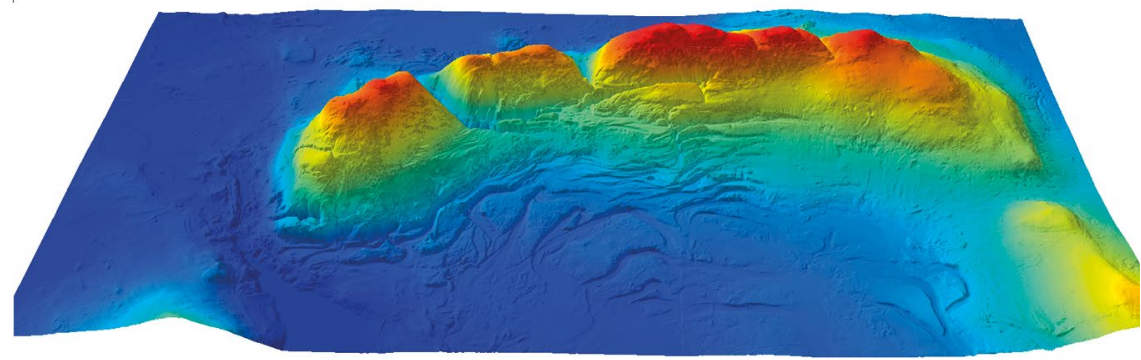

Figure 7. a) The Pyhätunturi fell chain of inselbergs composed of the Proterozoic quartzite rising from the fairly even lowlands (height range of the plain $180-220 \mathrm{~m}$ ) composed of less erosion resistant mafic volcanic rock, biotite paragneiss and arkose quartzite. The Pyhätunturi inselbergs fell tops from the left Kultakero (490 m), Ukonhattu (455 $\mathrm{m}$ ) and Noitatunturi (540 m) divided by canyons Isokuru (on the left) and Pikkukuru (on the right). Similar residual hills and inselbergs are common in the Proterozoic quartzite terrains of eastern and northern Finland. View from the fell of Luosto toward SE. b) the Pyhätunturi fell chain processed from LIDAR dem2 with ArcScene. The fell tops and canyons are in the same order from left to right as in Fig. 7 a. Width of the image is $10 \mathrm{~km}$, green arrow pointing to the north. Photo P. Johansson.

\subsection{Pyhätunturi inselberg in Pelkosenniemi}

Pyhä - Luosto is a 35-km-long fell range in La pland. In places, it rises to over $500 \mathrm{~m}$ a.s.l. The silhouette of this fell range, with its steep slopes and deep gorges, is visible in all directions from tens of kilometres away (Fig. 7a and b). It is aligned NW-SE and consists of approximately 2-Ga-old quartzite and conglomerate, which were formed as much older bedrock weathered and the sediments were deposited, and then underwent metamorphism during an orogeny (Mielikäinen, 1979; Räsänen \& Mäkelä, 1988). The fells are actually residual hills or inselbergs that have resisted erosion better than the surrounding rock types over millions of years. The highest fells of PyhäLuosto fell range are Pyhätunturi, Noitatunturi (540 m), Ukko-Luosto (514 m) and Pyhätunturi, Peurakero $(502 \mathrm{~m})$. The conglomerate bedrock can be seen everywhere, forming a belt around the lower southern slope of the mountain range. It is rhythmically bedded, consisting in many places of pebble beds that are tens of metres thick. Grey quartzite forms the upper slopes and tops of the fell range. Originally, the quartzite was quartz sand, sorted by running water, which then obtained its present appearance by undergoing metamorphism. The quartzite layers form beds about one metre thick. Horizontal or oblique series of beds alternate. In the horizontal beds, precipitate structures and ripple marks can occasionally be found. 


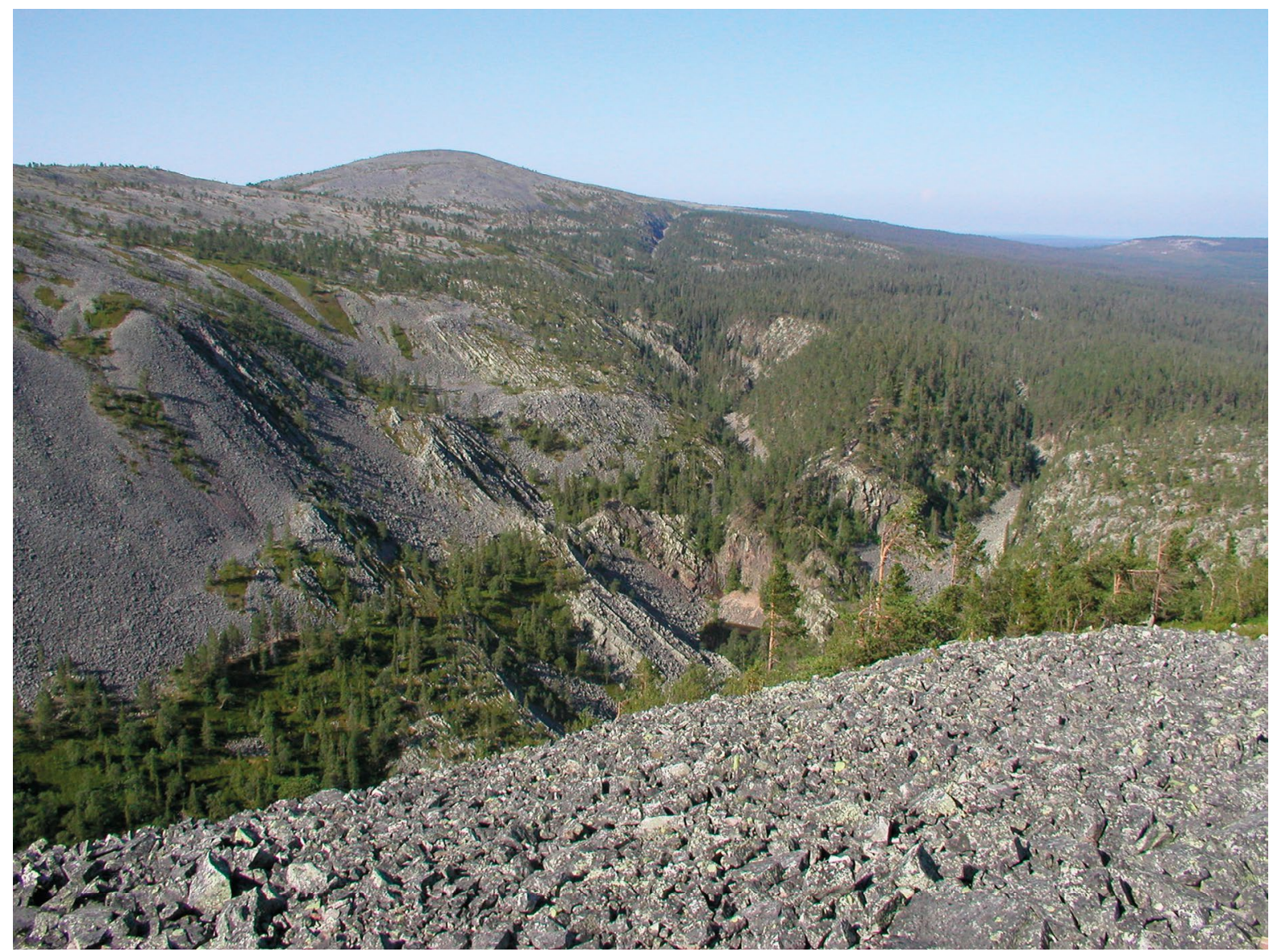

Figure 8. The Pyhätunturi, Noitatunturi inselberg is a residual hill of durable quartzite that has withstood erosion well. View from the top of the Pyhätunturi fell Kultakero. Between the fells there is the Isokuru Canoyn. Photo by P. Johansson.

Rugged canyons and gorges divide the fell range like huge cuts into several tops (Fig. 7). Isokuru, the most remarkable canyon of Pyhä, with a depth of $220 \mathrm{~m}$, is Finland's deepest canyon. About two kilometres further west lies a similar canyon, named Pikkukuru, with a depth of $130 \mathrm{~m}$. The formation of deep canyons was influenced by weakness zones in the bedrock, where deep fracturing had occurred due to movements in the Earth's crust millions of years before the last Ice Age. During the Quaternary period, ice lobes caused effective erosion and plucked blocks off the fractured bedrock. Finally, meltwater streams cleaned the canyon floors, carrying away loose rock material and spreading it at the mouths of the canyons, where it accumulated as gravelly outwash fans (Johansson et al., 2007).
The slopes of the Pyhätunturi, Noitatunturi fell (Fig. 8) are covered by block fields. They consist of quartzite bedrock that has been fractured in situ by frost weathering. In fell areas of the processes changing the ground surface after the Ice Age, frost weathering (congelifraction) has affected the landscape the most. It can be clearly observed, especially on the tops and upper slopes of the fells, where the climate is much harsher than in lower areas and is classified as nearly periglacial (Söderman, 1985). Due to weathering the rocks on the fell tops have broken down, so that they are now covered by metres thick angular blocks, called block fields (Söderman, 1985; Kejonen, 1997). 


\section{Discussion}

LiDAR datasets and lower resolution digital elevation models are powerful tools to analyse, calculate and study the geomorphology of large areas in Finnish Lapland. As the footprint of the laser scanning beam is $60 \mathrm{~cm}$ on the terrain and the scanning point density is at least 0.5 points $/ \mathrm{m}^{2}$, the accuracy of LiDAR information is phenomenal. Even the smallest details in ground are visible when the altitude accuracy in uncovered terrain is $15 \mathrm{~cm}$ in maximum. An advanced method is introduced to study the geomorphology of these bedrock fells or residual hill landscape in Finnish Lapland. Conventionally, topographical maps and elevation information derived from stereographic aerial photographs and digital map data were used.

Quaternary overburden covers most of the land areas in Finnish Lapland having variable thickness. On the areas of shallow till cover like in the hill tops, LiDAR data proves to show signs and remains of older geological structures and/or geomorphological formations even beyond the Quaternary overburden. In Lapland, the bedrock surface is usually weathered to grusses, sapropelite or even kaolinitic clay. On top of the residual hills, inselbergs the tor formations are frequent and evidently date back to pre-glacial times.

The inselbergs in Lapland rise from the peneplain to a height over $500 \mathrm{~m}$ a.s.l. and have the relative height of approximately $200-400 \mathrm{~m}$. Residual hills and inselbergs are not of the same bedrock type but they are composed of rock types (quartzite, granite, gabbro, granulite and volcanic rocks), which are more resistant to erosion than the surrounding low areas composed of mica and graphite schist and gneisses. In the light of this LiDAR experiment it is evident that the fells both in the Swedish and Finnish Lapland seems mostly to have developed as a result of long lasting erosion and weathering and thus fits well to the concept of inselberg or monadnock hill (Ebert et al., 2012; Lidmar-Bergström \& Olvmo, 2015).

We applied the LiDAR DEM to the same area studied earlier by Kaitanen (1985) in the eastern Finnish Lapland. This area belongs to the Central Lapland area known of relative deep preglacial weathered bedrock in the central part of the Fennoscandian Ice Sheet (e.g. Hirvas, 1991; Johansson et al., 2011). The weathering and erosion history of Lapland is long, as the kaolinite clays in the weathered bedrock could be of Late Cenozoic, Mesozoic or even Mesoproterozoic age (Sarapää, 1996; Hall et al., 2015). Has the deep weathering and erosion really stripped several hundreds of meters material out of the peneplain as many authors earlier has suspected and discussed? If the erosion had been continuous and even through all this time, so only $0.5-3 \mathrm{~m}$ would have been eroded through the Phanerozoic by one million year. In geological scale this is quite modest number, as erosion rates of nearly $50 \mathrm{~m}$ in one million years in tropical conditions has been reported (Thomas, 1994). In New South Wales in Australia erosion and weathering rate has been 6-20 m in million years (Taylor \& Eggleton, 2001). So the peneplanation and formation of inselbergs can be easily accomplished in the timeframe of the estimated weathering history of Lapland. Although all disconformities older than the Mesozoic era have probably been eroded to an unidentifiable extent, there is good reason to suppose that the main characteristics of the relief, including inselbergs, originated as early as the Late Cretaceous or at least in the Palaeocene.

Hättestrand \& Stroeven (2002) and André (2002) have observed and calculated that weathering rate in Sweden has been during Holocene less than $20 \mathrm{~mm}$ that equals $2 \mathrm{~m}$ in one million years. Stroeven et al. (2002) have also hypothetically estimated that weathering rate of the Parkajoki tor formations in Swedish Lapland would have been between about $1.6 \mathrm{~m}$ in one million year to result the formations in the timeframe of their probable to have formed in one million years. Hall et al. (2013) has estimated the rate of glacial erosion in Swedish Lapland to 9-27 $\mathrm{m}$ depending on the disposition eroded area, although they estimate the erosion of the hill tops to have been minor. Same calculations could be applied also to Pyhä-Nattanen 


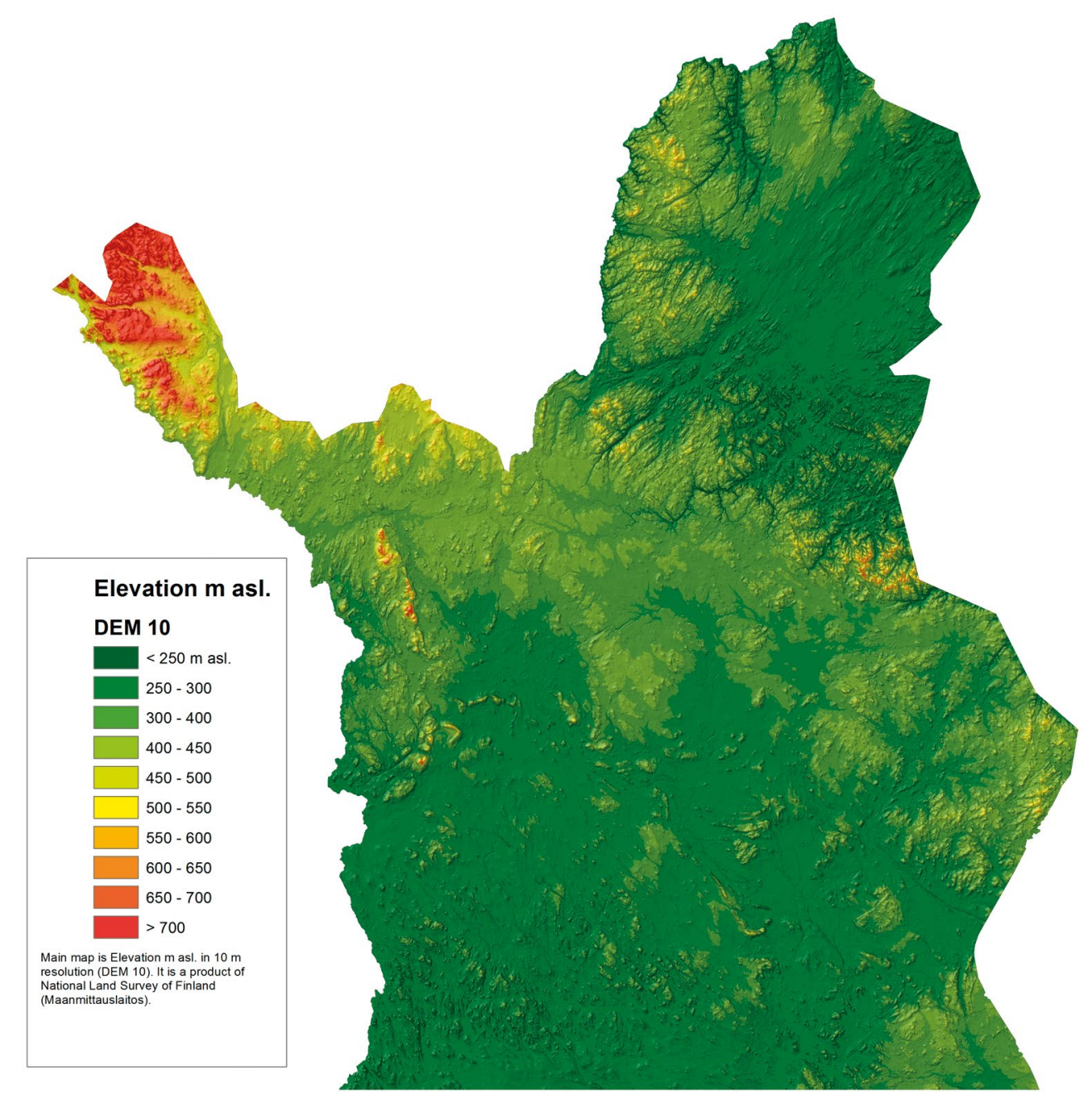

Figure 9. Elevation of the Lappish platform from DEM 10 grid elevation data of the National Land Survey of Finland. The inselbergs, fells in Finnish Lapland rise from the peneplain type platform to a height over $500 \mathrm{~m}$ a.s.I. having a relative height of $200-300 \mathrm{~m}$. Note the erosional river valleys in the north eastern Lapland round the Inari lake basin are dating back to preglacial times.

tors in Finnish Lapland giving erosion rate of the same order as presented by Darmody et al. (2008) and Hall et al. (2017). Estimates made from the upstanding tors may however be too modest, as glacial erosion has possibly removed rock material from their tops.

The LiDAR data has opened a view into the pre-glacial history and processes, enabling some preliminary evaluations of the rate and amount of pre-glacial erosion, or denudation, to be made (Fig. 9).

\section{Conclusion}

Main outcome of the LIDAR experiment in inselberg detection is that the LIDAR point cloud data provides mathematically accurate material for further geometrical and geomorphological analyses. The LiDAR DEM with $2 \mathrm{~m}$ grid and elevation accuracy $15 \mathrm{~cm}$ are giving possibility to calculate and study easily geomorphological features as inselbergs rapidly from large areas. The LIDAR 
data has many advances compared to the previous manual measuring and study of aerial photographs and topographic maps.

In this article, seven inselbergs from eastern Finnish Lapland were interpreted and analyzed. Most of them have tor formations on the top. LIDAR data gives detailed geometric information of the fell slopes thus enabling geological and geomorphological studies and observations of for example granitic sheet and fracture structures and solifluction slopes

As the inselbergs rise generally some $300 \mathrm{~m}$ from the surrounding peneplain, based on literature, it is suggested that the time for erosion since the Paleozoic is sufficient enough and can result the geomorphological inselberg terrain evolution in Finnish Lapland. The erosion and weathering has been evidently long lasting since early Paleozoic.

\section{References}

Ahnert, F., 1998. Introduction to Geomorphology. Arnold, London, $352 \mathrm{p}$.

André, M.-F., 2002. Rates of Postglacial rock weathering on glacially scoured outcrops (Abisko-Riksgränsen area, $\left.68^{\circ} \mathrm{N}\right)$. Geografiska Annaler 84 A, 139-150.

Darmody, R.G., Thorn, C.E., Seppälä, M., Campbell, S.W., Li, Y.K. \& Harbor, J., 2008. Age and weathering status of granite tors in Arctic Finland $\left(-68^{\circ} \mathrm{N}\right)$. Geomorphology $94,10-23$.

https://doi.org/10.1016/j.geomorph.2007.04.006

Ebert, K. \& Hättestrand, C., 2010. The impact of Quaternary glaciations on inselbergs in northern Sweden. Geomorphology 115, 56-66.

https://doi.org/10.1016/j.geomorph.2009.09.030

Ebert, K., Hall, A.M. \& Hättestrand, C., 2012. Pre-glacial landforms on a glaciated shield: the inselberg plains of northern Sweden. Norwegian Journal of Geology 92, $1-17$.

Ebert, K., Hall, A.M., Kleman, J. \& Andersson, J., 2015. Unequal ice sheet erosional impacts across low-relief shield terrain in northern Fennoscandia. Geomorphology 233, 64-74. https://doi.org/10.1016/j.geomorph.2014.09.024

Elo, S., Kuivasaari, T., Lehtinen, M., Sarapää, O. \& Uutela, A., 1993. Iso-Naakkima, a circular structure filled with Neoproterozoic sediments, Pieksämäki, southeastern Finland. Bulletin of the Geological Society of Finland 65, 3-30. https://doi.org/10.17741/bgsf/65.1.001
The fragmentary information of the few sedimentary sequences and dating of the tor formations in Lapland suggests that erosion rate have been possible in order of $2-10 \mathrm{~m}$ in one million years. Some remains of Tertiary clay and diatoms are found from eastern Lapland and show moist tropical or subtropical weathering conditions during the Cenozoic.

\section{Acknowledgements}

We thank Roy Siddall of the prompt and professional correction of our English. Furthermore, A. Hall and V.-P. Salonen are thanked for their critical and constructive comments to improve the manuscript.

Front, K., Vaarma, M., Rantala, E. \& Luukkonen, A., 1989. Keski-Lapin varhaisproterotsooiset Nattas-tyypin graniittikompleksit, niiden kivilajit, geokemia ja mineralisaatiot. Summary: Early Proterozoic Nattanen-type granite complexes in central Finnish Lapland: rock types, geochemistry and mineralization. Geological Survey of Finland, Report of Investigation 85, 1-77. (in Finnish with English summary)

Hall, A.M., Ebert, K. \& Hättestrand, C., 2013. Pre-glacial landform inheritance in a glaciated shield landscape. Geografiska Annaler: Series A, Physical Geography 95, 33-49. https://doi.org/10.1111/j.1468-0459.2012.00477.x

Hall, A.M., Sarala, P. \& Ebert, K., 2015. Late Cenozoic deep weathering patterns on the Fennoscandian Shield in Northern Finland: A window on ice sheet bed conditions at the onset of Northern Hemisphere glaciation. Geomorphology 246, 472-488. https://doi.org/10.1016/j.geomorph.2015.06.037

Hall, A.M., Ebert, K., Hätterstrand, C. \& Sarala, P., 2017. Long term geomorphology and weathering in northern Fennoscandia, In: Sarala, P. \& Johansson, P. (eds.), From past to present - Late Pleistocene, last deglaciation and modern glaciers in the center of northern Fennoscandia: Excursion guide and Abstracts: INQUA Peribaltic Working Group Meeting and Excursion 2017, 20-25 August 2017, Geological Survey of Finland, Rovaniemi, $7-15$. 
Hättestrand, C. \& Stroeven, A.O., 2002. A relict landscape in the centre of Fennoscandian glaciation: geomorphological evidence of minimal Quaternary glacial erosion. Geomorphology 44, 127-143. https://doi.org/10.1016/S0169-555X(01)00149-0

Heilimo, E., Halla, J., Lauri, L.S., Rämö, O., Huhma, H., Kurhila, M.I. \& Front, K., 2009. The Paleoproterozoic Nattanen-type granites in northern Finland and vicinity - a postcollisional oxidized A-type suite. Bulletin of the Geological Society of Finland 81, 7-38. https://doi.org/10.17741/bgsf/81.1.001

Hirvas, H., 1991. Pleistocene stratigraphy of Finnish Lapland. Geological Survey of Finland, Bulletin 354, 123 p.

Hirvas, H., Lagerbäck, R., Mäkinen, K., Nenonen, K., Olsen, L., Rodhe, L. \& Thoresen, M., 1988. The Nordkalott Project: studies of Quaternary geology in northern Fennoscandia. Boreas 7, 431-437. https://doi.org/10.1111/j.1502-3885.1988.tb00560.x

Holmes, A., 1978. Holmes' Principles of Physical Geology. Taylor \& Francis: New York.

Johansson, P. \& Palmu, J.-P., 2013. LiDAR data and elevation model used to produce information of geological landforms and development of ice lake stages. In: Damusyte, A. \& Grigiene, A. (eds.), INQUA Peribaltic Working Group. Abstracts of International Field Symposium. June 25-30, 38-39. Vilnius-Trakai.

Johansson, P., Ojala, A., Räisänen, J. \& Räsänen, J., 2007. PyhäLuosto: geologinen retkeilykartta - geological outdoor map: opaskirja - guidebook. Geologian tutkimuskeskus, Rovaniemi, $47 \mathrm{p}$.

Johansson, P, Lunkka, J.P. \& Sarala, P., 2011. The Glaciation of Finland. In: Ehlers, J., Gibbard, P.L. \& Hughes, P.D. (eds.), Quaternary Glaciations - Extent and Chronology - A closer look. Elsevier B.V., Developments in Quaternary Sciences, vol 15, chapter 9, 105-116. https://doi.org/10.1016/b978-0-444-53447-7.00009-x

Johnson, M., Fredin, O., Ojala, A.E.K. \& Peterson, G., 2015. Unraveling Scandinavian geomorphology: The LiDAR revolution. GFF 137, 245-251.

https://doi.org/10.1080/11035897.2015.1111410

Kaitanen, V., 1969. A geographical study of the morphogenesis of Northern Lapland. Fennia 99, 85 p.

Kaitanen, V., 1985. Problems concerning the origin of inselbergs in Finnish Lapland. Fennia 163, 359-368.

Kaitanen, V., 1989. Relationships between Ice-Sheet Dynamics and Bedrock Relief on Dissected Plateau Areas in Finnish Lapland North of 69 degrees Latitude. Geografiska Annaler, Series A, Physical Geography 71:1, 15 p. https://doi.org/10.1080/04353676.1989.11880269

Kejonen, A., 1997. Permafrost and patterned grounds in Finland - periglacial or something else. Bulletin of the Geological Society of Finland 69, 87-108. https://doi.org/10.17741/bgsf/69.1-2.008

Koivisto, S. \& Laulumaa, V., 2012. Pistepilvessä - Metsien arkeologiset kohteet LiDAR-ilmalaserkeilausaineistossa. Arkeologipäivät 2012, 51-67.
Lehtovaara, J.J., 1995. Kilpisjärven ja Haltin kartta-alueiden kallioperä. Summary: Pre-Quaternary rocks of the Kilpisjärvi and Haiti map-sheet areas. Geological map of Finland 1:100000. Explanation to the maps of PreQuaternary rocks, Sheets 1823 Kilpisjärvi and /842 Halti. (in Finnish with English summary)

Lidmar-Bergström, K., 1996. Long term morphotectonic evolution in Sweden. Geomorphology 16, 33-59. https://doi.org/10.1016/0169-555X(95)00083-H

Lidmar-Bergström, K. \& Olvmo, M., 2015. Plains, steps, hilly relief and valleys in northern Sweden - review, interpretations and implications for conclusions on Phanerozoic tectonics. Geological Survey of Sweden, Research Paper C 838, 42 p.

Mielikäinen, P., 1979. Pelkosenniemi. Geological map of Finland 1:100 000. Pre-Quaternary rocks, sheet 3642. Geological Survey of Finland, Espoo.

Migoń, P., 1996. Survival of Tertiary relief in highly glaciated areas of northern Europe. Czasopismo Geograficzne 67, 285-302.

Migoń, P., 1997. The geologic control, origin and significance of inselbergs in the Sudetes, NE Bohemian Massif, Central Europe. Zeitschrift für Geomorphologie 41, 4566.

Öhman, T. \& Preeden, U., 2013. Shock metamorphic features in quartz grains from the Saarijärvi and Söderfärden impact structures, Finland. Meteoritics \& Planetary Science 48, 955-975. https://doi.org/10.1111/maps. 12112

Ojala, A.E.K., Putkinen, N., Palmu, J.-P. \& Nenonen, K., 2015. Characterization of De Geer moraines in Finland based on LiDAR DEM Mapping. GFF 137, 304-318. https://doi.org/10.1080/11035897.2015.1050449

Putkinen, N., Eyles, N., Putkinen, S., Ojala, A., Palmu, J.-P., Sarala, P., Väänänen, T., Räsänen, J., Saarelainen, J., Ahtonen, N., Rönty, H., Kiiskinen, A. \& Tervo, T., 2017. High-resolution LiDAR mapping of the ice stream lobes in Finland. Bulletin of the Geological Society of Finland 89:2, 64-81. https://doi.org/10.17741/bgsf/89.2.001

Räsänen, J. \& Mäkelä, M., 1988. Early Proterozoic fluvial deposits in the Pyhätunturi area, northern Finland. Geological Survey of Finland, Special Paper 5, 239-254.

Risbøl, O., Gjertsen, A.K. \& Skare, K., 2008. Flybåren laserskanning og registrering av kulturminner i skog. Fase 3. (English abstract: Airborne laser scanning of cultural remains in forest. Phase 3.) NIKU Rapport 22, 43 p.

Rudberg, S., 1960. Geology and Morphology. In: Somme, A. (ed.), A Geography of Norden J.W.Cappelens forlag, Oslo, 362 pp.

Sarala, P., Räisänen, J., Johansson, P. \& Eskola, K.O., 2015. Aerial LiDAR analysis in geomorphological mapping and geochronological determination of surficial deposits in the Sodankylä region, northern Finland. GFF 137, 293 303.

https://doi.org/10.1080/11035897.2015.1100213 
Sarapää, O., 1996. Proterozoic primary kaolin deposits at Virtasalmi, southeastern Finland. Geological Survey of Finland, Special Publication 18b, 152 p.

Söderman, G., 1985. Planation and weathering in eastern Fennoscandia. Fennia 163, 347-352.

Stroeven, A.P., Fabel, D., Hättestrand, C. \& Harbor, J., 2002. A relict landscape in the centre of fennoscandian glaciations: cosmogenic radionuclide evidence of tors preserved through multiple glacial cycles. Geomorphology 44, 145-154.

https://doi.org/10.1016/S0169-555X(01)00150-7

Taylor, G. \& Eggleton, R.A., 2001. Regolith Geology and Geomorphology. John Wiley \& Sons Ltd., Chichester,
New York, Weinheim, Brisbane, Singapore, Toronto, $375 \mathrm{p}$.

Thomas, M.F., 1965. Some aspects of the geomorphology of domes and tors in Nigeria. Zeitschrift für Geomorphologie 9, 63-81.

Thomas, M.F., 1978. The study of inselbergs. Zeitschrift für Geomorphologie 31, 1-41.

Thomas, M.F., 1994. Geomorphology in the Tropics: A Study of Weathering and Denuation in Low Latitudes. John Wiley \& Sons Ltd., Chichester, 482 p.

Tynni, R. \& Uutela, A., 1985. Late Precambrian shale formation of Taivalkoski in northern Finland. Geologi 37, 61-65. (In Finnish, with an English summary) 